\begin{tabular}{llllllllll}
$N$ & $E$ & $K$ & $R$ & $O$ & $L$ & $O$ & $G$ & I \\
\hline
\end{tabular}

\title{
ŚP. KS. PROF. DR HAB. LECH REMIGIUSZ STACHOWIAK (1926-1997)
}

Na początku czerwca, w gronie redakcji „Biblii Częstochowskiej”, odwiedziliśmy Profesora w jego skromnym mieszkaniu w Łodzi. Nic nie wskazywało wówczas, że jest to nasze ostatnie ziemskie spotkanie. Wspominał o niedawnym zjeździe koleżeńskim w rodzinnej Wrześni, z okazji 50-lecia matury. Snuliśmy plany dalszej wspołpracy, licząc na jego fachową pomoc. Przyjął chętnie przekazane Mu do oceny przekłady ksiąg biblijnych, obiecując zabrać się do nich w lipcu. Śmierć przyszła nagle w dniu 1 sierpnia; dowiedziałem się o niej $\mathrm{z}$ wiadomości Radia Watykańskiego w dniu pogrzebu. Nie mogąc spełnić obowiązku „pogrzebania ze czcią ciala” zmarlego Profesora, pragnę tym wspomnieniem oddać hołd wybitnemu uczonemu i gorliwemu kapłanowi.

\section{1. ŻYCIORYS}

Lech Remigiusz Stachowiak urodził sig 24 maja 1926 roku w Poznaniu z matki Stanisławy z d. Chudzińskiej i ojca Ignacego Stachowiaka, porucznika W.P., inspektora Zakładu Ubezpieczeń Wzajemnych w Poznaniu. Wykształcenie podstawowe i średnie otrzymal we Wrześni w woj. poznańskim. Jesienią roku 1939 wysiedlony z terenów zajętych przez Rzeszę, spędził wraz $\mathrm{z}$ rodzicami lata okupacji $\mathrm{w}$ województwie kieleckim. Po powrocie do Wrześni w r. 1945, ukończył tam naukę w Państwowym, Gimnazjum i Liceum o profilu humanistycznym. Świadectwo dojrzałości otrzymał w czerwcu 1947, i w tym samym roku wstapił do Wyższego Seminarium Duchownego w Łodzi. Po dwu latach studiów filozoficznych, w październiku r. 1949, został skierowany przez bpa Michała Klepacza na dalsze studia teologiczne do Fryburga Szwajcarskiego. Tam też otrzymał święcenia kapłańskie z rąk bpa Fr. Charrière w dniu 20 sierpnia $1952 \mathrm{r}$.

Dalsze studia uniwersyteckie odbywał nadal we Fryburgu, pod kierunkiem dominikańskich egzegetów tej miary co M. E. Boismard, F. M. Braun czy C. Spicq. Ten astatni był promotorem pracy doktorskiej ks. Stachowiaka z zakresu biblistyki (22.6.1955), ocenionej "summa cum laude" i ogłoszonej drukiem we Fryburgu w r. 1957. Zaraz po doktoracie rozpoczął ks. Stachowiak specjalistyczne studia w Papieskim Instytucie Biblijnym w Rzymie, osiągając kolejno bakalaureat (1956), licencjat (1957) i kandydaturę ad doctoratum (1958). W roku 1958 uczestniczył też w naukowej podróży do Libanu, Syrii, Jordanii, Egiptu i Izraela, celem zapoznania się $\mathrm{z}$ badaniami archeologicznymi (Qumran) i topografią krajów biblijnych. 
Wyprawie tej przewodniczył szwajcarski profesor Herbert Haag, twórca sławnego Bibel-Lexikon (w leksykonie Haaga znajdą się później liczne hasła przygotowane przez ks. Stachowiaka).

Po powrocie do kraju w r. 1958, ks. Stachowiak zostal profesorem Pisma świętego i zarazem wychowawcą w Wyższym Seminarium Duchownym w Łodzi. Jednocześnie przygotowywał pod kierunkiem prof. K. Prümma SJ rozprawę doktorską z zakresu nauk biblijnych, którą w r. 1962 przedłożył w Papieskim Instytucie Biblijnym. Praca ta, zatytułowana Die paulinischen Paränesen und die Unterweisung über die zwei Geister in Qumran, zyskała ocenę „summa cum laude" i zapewniła Mu tytuł doktora nauk biblijnych. W r. 1963 uzyskał na Katolickim Uniwersytecie Lubelskim stopień doktora teologii na podstawie ogublikowanej uprzednio pracy Chrestotes, ihre biblisch-theologische Entwicklung und Eigenart. Ówczesny rektor KUL, ks. prof. Marian Rechowicz, zaproponowal Mu wówczas podjęcie dalszej pracy naukowej w kierunku habilitacji. W roku 1966 został powołany w skład Komisji Kwalifikacyjnej, jaka przy niemożności wyjazdów na studia rzymskie miała nadawać $\mathbf{w}$ KUL-u uprawnienia do wykładania katolickiej biblistyki w Polsce. W tym samym roku ks. rektor Granat powierzył $\mathrm{Mu}$ wykłady na sekcji biblijnej KUL-u. Rozprawa habilitacyjna, będąca podsumowaniem dotychczasowych badań ks. dra Stachowiaka, została przedstawiona do oceny Wgdziałowi Teologicznemu KUL w maju 1967 roku pt. Geneza i rozwój dualistycznej antropologii qumrańskiej. Kololowium habilitacyjne (25.11.1967) było podstawą nadania ks. Stachowiakowi tytułu naukowego docenta, zatwierdzonego $\mathrm{w}$ następnym roku przez Ministerstwo Szkolnictwa Wyższego. Wówczas też Rada Wydziału Teologicznego KUL powierzyła Mu Katedrę Filologii Biblijnej, która po reorganizacji Szkoły Biblijnej została przemianowana na I Kat. Egzegezy Ksiąg ST. Profesorem nadzwyczajnym mianowano Go w r. 1974, a profesorem zwyczajnym w r. 1981.

Do przejścia na emeryturę (1996) dojeżdżał systematycznie z Łodzi do Lublina $\mathrm{z}$ wykładami, pełniąc jednocześnie szereg funkcji na KUL-u. Przez kilka kadencji był przewodniczącym Senackiej Komisji do spraw Nauki. Był też czynnym członkiem Towarzystwa Naukowego KUL (od r. 1983) oraz Międzynarodowej Organizacji Studiów nad ST (IOSOT, od r. 1977). Z licznych prac redakcyjnych należy wymienić zwłaszcza redakcję Biblii Tysiąclecia (Stary Testament, od r. 1970), serii komentarzy KUL-owskich do ST w „Pallottinum” (od 1978), czy tzw. „Biblii Lubelskiej” (St. od r. 1986). W Encyklopedii Katolickiej KUL kierował redakcją działu teologii biblijnej a od r. 1985 współredagował poczytną serie książkową Jak rozumieć Pismo św. W latach 1988-1993 pełnił obowiązki przewodniczącego biblistów polskich, organizując doroczne sympozja biblijne. Do najbardziej prestiżowych wyróżnień ks. prof. Stachowiaka należy członkostwo w Papieskiej Komisji Biblijnej (od 15.1.1990 roku do śmierci). Wiązało się to z uciążliwymi wyjazdami każdego roku na sesje do Rzymu. Po upływie pięcioletniej kadencji prosił więc o zwolnienie $\mathrm{z}$ tych prac; na osobistą prośbę Ojca św. pozostał jednak do końca. Te wszystkie prace, a zwłaszcza wyjątkowe kompetencje naukowe, zapewnily ks. Profesorowi w gronie polskich biblistów szczególny prestiz. 


\section{DOROBEK NAUKOWY}

Chcąc scharakteryzować niezwykle bogatą twórczość naukową ks Stachowiaka, trzeba przypomnieć, iż blisko 40 lat (od 1958 do śmierci) wykładał On egzegezę całego Pisma św. w Łódzkim Seminarium Duchownym i tamtejszej filii Akademii Teologii Katolickiej. Tak szeroki zakres wykładów, w połączeniu ze specjalistycznymi badaniami w ramach prac katedry na KUL-u, pozwolil na dokonanie cennych syntez, zarówno w formie monografii książkovych jak i artykułów encyklopedycznych. Cechowała je zawsze oryginalność ujęć i znajomość najnowszych nurtów w biblistyce światowej.

Główną dziedziną zainteresowań Profesora była egzegeza tekstu Starego i Nowego Testamentu. Poświadczeniem tego nurtu pracy są wielkie komentarze biblijne: do Ksiegi Jeremiasza (1967), Barucha i Lamentacji (1968), Ewangelii św. Jana (1975) i do Izajasza i (1996). Pozwalają one wniknąć w bogactwo warsztatu naukowego i potwierdzają rzetelne przygotowanie do trudnej pracy egzegety. Dzięki świetnej znajomości języków obcych, zwłaszcza niemieckiego, wyniki badań ks. Stachowiaka są dostępne również poza granicami Polski. Z egzegezą wiąże się ściśle szereg przekładów ksiąg biblijnych $\mathrm{z}$ języków oryginalnych. Oprócz wymienionych wyżej trzeba tu wymienić tłumaczenie Listu Jakuba w Biblii Tysiąclecia (1965), a w jej następnych wydaniach także przekład Psalmów i Księgi Daniela (1971). Ucząc języka aramejskiego, nieraz zwracałem uwagę studentów na solidność tego ostatniego przekładu.

Zainteresowania filologiczne ks. Profesora zdradzają artykuły poświęcone wokalizacji rękopisów qumrańskich w świetle materiałów porównawczych. Oprócz materiału dydaktycznego znajdujemy tam wiele cennych spostrzeżeń $z$ dziedziny gramatyki i fonetyki hebrajskiej w jej historycznym rozwoju. Syntetyczne spojrzenie na kwestie filologiczne zawiera artykuł Biblijne języki w EK II.

Obok filologii, poczesne miejsce $\mathrm{w}$ badaniach ks. Stachowiaka zajmowały zawsze zagadnienia historyczno-biblijne, równie istotne dla współczesnej egzegezy. Przykladem może być nowa interpretacja historycznych uwarunkowań tradycji kapłańskiej. Przedstawił ją Profesor $w$ referacie o tzw. „przykazaniu noachickim” poczas światowego kongresu biblistów w Wiedniu w sierpniu $1980 \mathrm{r}$. W późniejszych pracach wiele uwagi poświęcał także środowisku historycznemu, w jakim powstawała Księga Izajasza.

Kolejną dziedziną zainteresowań ks. Stachowiaka była teologia biblijna. Zagadnienia teologiczne jako wynik krytycznej egzegezy tekstu podejmował On zwlaszcza w odniesieniu da najdawniejszych tradycji literackich Starego Testamentu, przedstawiając je w kolejnych etapach rozwojowych. Synteza tych tematów pojawia się często w monograficznych artykułach Encyklopedii Katolickiej. Szczególne miejsce w swych badaniach poświęcał tradycjom etycznym, zarówno w ścisłym jak i w szerszym znaczeniu tego słowa. Zupełną nowością jest podjęty juz w doktoracie temat historii parenezy biblijnej na tle tradycji mądrościowych. Autor wskazuje na środowiska, w jakich taka refleksja się rozwijała, oraz na czynniki sprzyjające jej rozwojowi. Najważniejsze opracowania $\mathrm{z}$ tego cyklu, napisane po niemiecku, kreślą linię łączącą początki mądrości sentencjonalnej, pielęgnowanej 
przez „starszych" i przekazywanej ustnie, z formalnymi parenezami grupującymi te popularne refleksje etyczne w charakterystyczne zbiory, których przekładów dostarcza literatura międzytestamentalna. Na tym tle rozwija się w NT pouczenie moralne stanowe, wraz z szeregiem gatunków literackich, jak katalogi cnót, kodeksy postępowania w rodzinie itp.

$\mathrm{Na}$ koniec trzeba wspomnieć o opracowaniu przez ks. Stachowiaka historii polskiej biblistyki. Dotychczas istniały w tej dziedzinie tylko drobne przyczynki, szczególnie zaś zaniedbany był okres XIX wieku. W ramach wielotomowej Historii Teologii Katolickiej w Polsce (pod. red. ks. bpa Rechowicza) przedstawil ks. Stachowiak rozwój biblistyki pod trzema zaborami, a następnie w początkach niepodległości Polski. Te trudne dziesięciolecia ilustruja powolny wzrost refleksji egzegetycznej na ziemiach polskich. Pozwala to dostrzec, jak wyzwalała się ona z zależności apalogetycznych, z funkcji czysto pastoralnych, aby wreszcie dołączyć do głównego nurtu naukowych badań biblijnych. Uzupełnieniem tego opracowania jest artykuł Katolicka biblistyka polska 1900-1945. Tu akcent spoczywa na latach międzywojennych, kiedy to polska biblistyka stała się prawdziwie współczesną.

Skrótowe z konieczności opracowanie dorobku naukowego ks. prof. L. R. Stachowiaka wskazuje na rozległość Jego zainteresowań i na ogromny wkład w naukową biblistykę polską. Princeps exegetarum Poloniae $\mathrm{z}$ całą pewnością zasługuje na szereg szczegółowych prac, które ukażą ten dorobek bardziej całościowo i dogłębnie. Jako Jego uczeń i współpracownik, muszę na koniec podkreślić Jego walory dydaktyczne i wielką kulturę osobistą. To wszystko pozwala żywić nadzieję, że Jego trud wychowawczy i wzór Uczonego będą długo owocowały w przyszłych pokoleniach polskich biblistów.

Lublin

Ks. ANTONI TRONINA

BIBLIOGRAFIA PUBLIKACJI KS. PROF. L. R. STACHOWIAKA

1956

1. Der Christ und die Güte. „Schweitzerische Kirchenzeitung” 124 (1956) 433-435. 464-466.

1957

2. Chrestotes, ihre biblisch-theologische Entwicklung und Eigenart. Fribourg (Suisse) 1957, ss.VI+ 137 (Studia Friburgensia NF 17).

1958

3. Hoffnung und Verzweiflung in biblischer Sicht, „Anima” 13 (1958) 111-118 (wspólnie z H. Haagiem).

1959

4. Güte, art. w: Bibeltheologisches Wörterbuch (wyd. J. B. Bauer), Graz 1959 (3. wyd.1967), 648-657. 


\section{0}

5. [Rec.]: E. Pax Epiphaneia. München 1955, RBL 13 (1960) 365-369.

6. Refleksje nad biblijnym pojęciem pokory, RBL 13 (1960) 199-216.

\section{1}

7. Dzieje ostatnich sporów biblijnych, „Znak” 13 (1961) 943-969.

8. Etyka Zrzeszenia z Qumran a etyka św. Pawła, w: Ze wspólczesnej problematyki biblijnej. Lublin 1961, s. 115-130.

\section{3}

9. Die Antithese Licht - Finsternis, ein Thema paulinischer Paränese, „Tübingen Theologisches Zeitschrift” 143 (1963) 385-421.

10. Paraenesis paulina et Instructio de duobus spiritibus in "Regula Qumranensi”, „Verbum Domini” 41 (1963) 245-250.

11. Człowiek między światłem a ciemnością według św. Pawła, w: Studia biblijne i archeologiczne. Poznań 1963, 179-197.

12. Modlitwa w Piśmie św. AK 66 (1963) 299-309.

\section{4}

13. Teologiczno-biblijna problematyka czasu, RBL 17 (1964) 291-303.

14. Traktat teologiczno-moralny o dwóch duchach w regule Zrzeszenia z Qumran, AK 67 (1964) 219-228.

\section{5}

15. List św. Jakuba, w: Pismo święte Starego i Nowego Testamentu (Biblia Tysiąclecia) w przekładzie z języków oryginalnych, Poznań 1965 (i kolejne wydania).

\section{6}

16. V Międzynarodowy Kongres Studiów Starego Testamentu w Genewie, CT 36 (1966) 238-244.

\section{7}

17. Spór między Jahwe a Izraelem (Jr 2,1-20), RBL 20 (1967) 72-85.

18. Jeremiasz - prorok Izraela, CT 37 (1967) 35-48.

19. [Rec.] Księga Jeremiasza w BT wyd. 1, RTK 14 (1967) 89-92.

20. Księga Jeremiasza. Wstęp, przeklad $\mathrm{z}$ oryginalu, komentarz. Poznań 1967, ss. 536 (PSST X, 1).

21. Hass, art w: Bibeltheologisches Wörtrerbuch (wyd. J. B. Bauer), Graz 1967 (wyd. 3) s. 664-669.

21a. Teologiczny temat dwóch duchów w pismach qumrańskich, ZN KUL 10 (1967) z. 3, s. 37-52.

\section{8}

22. Fäulnis, art. w: Bibel-Lexikon (wyd. H. Haag), Einsiedeln 1968 (wyd. 2), kol. 472-473.

23. Güte, art. tamże, kol. 646.

24. Langmut, art. tamże, kol. 1015.

25. Sanfmut, art. tamże, kol. 1521. 
26. Sauerteig, art. tamże, kol. 1528.

27. Verfolgung; art. tamże, kol. 1816-1817.

28. Vielen (die), art. tamże, kol. 1848-1849.

29. Lamentacje. Księga Barucha. Wstęp, przekład z oryginału, komentarz. Poznań 1968, ss. 182 (PSST X, 2).

30. Biblijna koncepcja człowieka, w: W nurcie zagadnień posoborowych, t. 2. Warszawa 1968 , s. 209-226.

\section{9}

31. W poszukiwaniu chrześcijańskiego sensu Starego Testamentu, AK 72 (1969) 418-426.

32. Bóg działa w historii zbawienia ku Chrystusowi, WDŁ. 43 (1969) $243-257$.

33. Geneza dydaktycznego schematu dwóch dróg w piśmiennictwie qumrańskim i międzytestamentalnym, RBL 22 (1969) 75-85.

34. Zagadnienie dualizmu antropologicznego $\mathrm{w}$ Starym Testamencie i literaturze międzytestamentalnej, STV 7 (1969) nr 2, s. 3-32.

\section{0}

35. Teologia życia w Starym Testamencie, RTK 17 (1970) z. 1, s. 12-21.

36. Pouczenia moralne w starszych tradycjach prorockich, ZN KUL 13 (1970) nr 1, s. 3-10. 234

37. Nowe wydanie krytyczne Biblii Hebrajskiej, RBL 23 (1970) 232-

\section{1}

38. Na ile prawdy i normy Starego Testamentu zachowaly wartość dla kształtowania dzisiejszej doktryny moralnej, AK 76 (1971) 208-218.

39. Apokaliptyka i eschatologia u progu ery chrześcijańskiej, AK 77 (1971) 57-68.

40. Historia i eschatologia u proroków, RTK 18 (1971) z. 1, s. 85-95.

41. Księga Jeremiasza, w: Pismo święte Starego i Nowego Testamentu (Biblia Tysiąclecia), wyd. 2, Poznań 1971., s. 907-968.

42. Księga Daniela, tamże, s. 1030-1050.

43. Księga Psalmów, tamże, s. 570-711 (współtłumacz A. Jankowski).

\section{2}

44. Odwieczne pochodzenie Słowa (J 1,1-5), RBL 25 (1972) 156-168.

45. Symboliczne czynności jako forma przekazu prorockiego, w: Współczesna biblistyka katolicka (1945-1970). Red. J. Łach, M. Wolniewicz, Warszawa 1972 , s. 79-90.

46. Starotestamentalna koncepcja Boga, RTK 19 (1972) z. 1, s. 61-72.

\section{3}

47. [Rec.]: Ist Adam am allem schuld? Pr. zbior. Innsbruck 1971. STV 11,2 (1973) 327-333.

48. Adam, art w EK I (1973), kol. 67-70.

49. Alleluja, tamże, kol. 377-378.

50. Amhaarec, tamże, kol. 454. 
51. Angelofania, tamże, kol. 549. 607.

52. Anioł w ST i literaturze międzytestamentalnej, tamże, kol. 605-

53. Antropologia biblijna - ST, tamże, kol. 690-692.

54. Antropomorfizm w Piśmie św., tamże, kol. 703.

55. Apokaliptyka, tamże, kol. 753-755.

56. Apokryfy ST, tamże, kol. 758-761.

57. Asceza - judaizm, tamże, kol. 785-786.

58. Aszera, tamże, kol. 1022-1023.

59. Asztarte, tamże, kol. 1023.

60. Baal, tamże, kol. 1227-1228.

61. Babilońska niewola, tamże, kol. 1238-1239.

62. Baltazar, tamże, kol. 1289.

63. Balchochwalstwo, tamże, kol. 1295-1296.

64. Rozwój norm moralnych w historii zbawienia Starego Testamentu, AK 81 (1973) 39-49.

65. Spotkanie Jezusa z Nikodemem, RTK 20 (1973) z. 1, s. 69-81.

66. Literackie $\mathrm{i}$ egzegetyezne problemy perykopy o chlebie $\mathrm{z}$ nieba (J 6,22-59), STV 11,2 (1973) 57-74.

67. Teologia słowa prorockiego w Starym Testamencie, w: Z zagadnień kultury chrześcijańskiej, Warszawa 1973, 111-118.

68. Prorocy i księgi prorockie, w: Wstęp do Starego Testamentu (red. S. Łach), Poznań 1973, 373-500.

\section{4}

69. Godność mesjańska Jezusa w Ewangelii Janowej, w: Mesjasz w biblijnej historii zbawienia (red. S. Łach), Lublin 1974, 363-373.

70. Modlitwa arcykapłańska (J 17), RTK 21 (1974) z. 1, s. 85-94.

71. Bóg w pismach starotestamentalnych i literaturze międzytestamentalnej, w: O Bogu dziś (red. B. Bejze), Warszawa 1974, 155-170.

72. Eschatologia Ewangelii wedlug św. Jana, w: Materialy Kongresu Biblistów w Krakowie (red. S. Grzybek i J. Chmiel), Kraków 1974, 150173.

73. Pismo święte o powstaniu życia, AK 83 (1974) 371-382.

74. Jak rozumieć biblijne wypowiedzi o człowieku, STV 12,1 (1974) $167-176$.

\section{5}

75. Ewangelia według św. Jana. Wstęp, przekład z oryginału, komentarz. Poznań 1975, ss. 456 (PSNT IV).

76. Ewangelia według św. Jana, w: Komentarz praktyczny do Nowego Testamentu. Poznań 1975, 359-514.

77. List św. Jakuba, tamże, 1041-1066.

78. Pierwszy list św. Piotra, tamże, 1067-1090.

78. Drugi list św. Piotra, tamże, 1091-1104.

80. Pierwszy list św. Jana, tamże, 1105-1127.

81. Drugi list św. Jana, tamże, 1128-1130.

82. Trzeci list św. Jana, tamże, 1131-1133. 
83. List w. Judy, tamże, 1134-1138.

84. Dobry Pasterz (J 10,1-21), RTK 22 (1975) z. 1, s. 75-84.

85. Tematy teologiczno-biblijne: choroba, uzdrowienie, problematyka zła, WDŁ. 49 (1975) 80-88.

86. Filologiczne uwagi do Reguły Zrzeszenia, w: Materiały do wykładów z biblistyki (red. S. Łach, M. Filipiak), Lublin 1975, 167-183.

\section{6}

87. Elementy eklezjalne w objawieniu Starego Testamentu, ZN KUL 19 (1976) nr 1, s. 11-21.

88. Rozwój nauk biblijnych w XIX i pocz. XX wieku, w: Dzieje teologii katolickiej w Polsce w wieku XIX i XX (red. M. Rechowicz), t. 3, Lublin $1976,33-66$.

89. Ostatni dialog Jezusa z niewierzącym światem, w: Warszawskie Studia Biblijne (red. J. Frankowski, B. Widła), Warszawa 1976, 111-120.

90. Auf den Spuren der Paränese im Alten Testament, CT 46 (1976) fasc. spec., s. 58-79.

91. Królestwo Boże w najstarszych tradycjach Starego Testamentu, w: Królestwo Boże w Piśmie świętym (red. S. Lach, M. Filipiak), Lublin 1976, 11-16.

92. Osiem błogoslawieństw na tle pojęć etycznych mieszkańców Palestyny w epoce Chrystusa, RTK 23 (1976) z. 1, 49-59.

93. Baranek - ST, art. w EK II (1976), kol. 4.

94. Bar Kochba, tamże, kol. 33.

95. Baruch, tamże, kol. 89-90.

96. Barucha księga, tamże, kol. 90-91.

97. Belial, tamże, kol. 201.

98. Biblia III. Tekst ST, tamże, kol. 389-394.

99. Biblijna teologia - ST, tamże, kol. 469-472.

100. Biblijne języki, tamże, kol. 476-481.

101. Biblijny styl, tamże, kol. 492-494.

102. Bluźnierstwo - ST, tamże, kol. 669-670.

103. Błogosławieństwo - ST, tamże, kol. 682-683.

104. Bojaźń Boża - ST, tamże, kol. 740-741.

105. Bóg w ST, tamże, kol. 902-909.

\section{7}

106. A Bogiem było Słowo $(J$ 1,1). Pochodzenie i sens Janowego określenia Logos, w: Studia z filozofii Boga t. 3 (red. B. Bejze), Warszawa (1977) 121-123.

107. Osiem błogosławieństw na tle pojęć etycznych mieszkańców Palestyny, w: Bóg, Dekalog, Błogosławieństwa, Modlitwa (red. A. Święcicki), Kraków 1977, 135-147.

108. Filologiczne uwagi do Reguly Zrzeszenia, cz. 2, w: Materiały pomocnicze do wykładów z biblistyki, t. 2 (red. S. Łach, M. Filipiak, H. Langkammer), Lublin 1977, 141-163.

109. Grzech narodu i możliwość ratunku według Iz 1,2-17, RTK 24 (1977) z. 1, s. 5-9. 


\section{8}

110. Międzynarodowy Kongres International Organization for the Study of the Old Testament w Götingen (21-26 VIII 1977), ZN KUL 21 (1978) nr 1, s. 90-91.

111. W poszukiwaniu parenezy w Starym Testamencie, CT 48 (1978) fasc. 2, s. 35-57.

112. Pouczenia etyczne w literaturze międzytestamentalnej, CT 48 (1978) fasc. 3, s. 43-62.

113. Katolicka biblistyka polska 1900-1945, w: W kierunku kultury chrześcijańskiej, Warszawa 1978, 551-567.

114. Die sittlichen Mahnungen in der intertestamentalen Literatur, CT 48 (1978) fasc. spec., s. 4160.

115. Prorocy jako zjawisko religijne starożytnego Wschodu, RTK 25 (1978) z. 1, s. 23-36.

116. Problematyka zła w Starym Testamencie, w: Studio lectionem facere (red. S. Lach, J. Szlaga), Lublin 1978, 198-202.

117. Idea życia po śmierci, tamże, 217-2 20.

118. Die „ekklesialen” Bilder und Formen im Alten Testament, ZN KUL 21 (1978) nr. spec., s. 49-57.

\section{9}

119. Dwa aktualne zagadnienia teologiczno-biblijne, w: MPWB t. 3 , Lublin 1979, 99-106.

120. Posłannictwo Deuteroizajasza w świetle Iz 40,1-11 i późniejszej tradycji tego tekstu, STV 17 (1979) nr 1, s. 57-70.

121. Nadchodzący dzień Jahwe (Iz 2,6-22), RTK 26 (1979) z. 1, s. 25-34.

122. Charyzmat, art w: EK III (1979), kol. 92-93.

123. Chasydyzm, tamże, kol. 101-102.

124. Chrzest Janowy, tamze, kol. 368-370.

125 Ciało ludzkie - ST, tamże, kol. 443-444.

126. Cierpienie - ST, tamże, kol. 478-479.

127 Cierpliwość - ST, tamże, kol. 481.

128. Cud - S'T, tamze, kol. 645-648.

129. Daniel, tamże, kol. 1003-1004.

130. Daniela Księga, tamże, kol. 1010-1011.

\section{0}

131. Die Paränese im Qumran-Schrifttum, Folia Orientalia 21(1950) $117-128$.

132. Wizja chwały Jahwe a misja Izajasza proroka (Iz 6,1-13), RTK 27 (1980) z. 1, s. 15-26.

133. Wartości etyczne tradycji o przymierzu, w: Biblia księga życia Ludu Bożego (red. S. Łach, M. Filipiak), Lublin 1980, 19-27.

134. Odpuszczenie grzechów w pismach prorockich, tamże, 61-70.

135. Ks. Aleksy Klawek jako egzegeta i thumacz Biblii, RBL 33 (1980) 191-201.

136. Prorocy - słudzy słowa, Katowice 1980, ss. 285.

137. Biblijny obraz małżeństwa: od Starego do Nowego Testamentu, ZN KUL 23 (1980) nr 3, s. 17-24. 


\section{1}

138. Wyrok na Babilon w ocenie Iz 13,1-22, RTK 28 (1981) z. 1, s. 13-23.

139. Der Sinn der sogennante noachitischen Gebote (Gen IX, 1-17), w: Congress Volume Vienna 1980, Leiden 1981, 395-404 (Vetus Testamentum Supplement 32).

140. Die Prophetie als religiöses Phänomen des Alten Orients; w: Dein Wort beachten, Leipzig 1981, 58-75.

141. Die Sendung Deuterojesajas im Lichte von Jes 40,1-11, tamże, $102-115$.

142. Komentarze do czytań biblijnych ( $\mathrm{Iz}, \mathrm{Jr}, \mathrm{Ba}, \mathrm{J})$, w: Komentarze biblijne do czytań liturgicznych red. S. Lach, t. 1-4. Lublin 1981.

\section{2}

143. Idea życia po śmierci w Starym Testamencie, w: MPWB t. 5, Lublin 1982, 9-26.

144. Biblijny obraz małżeństwa, tamże, 163-168.

145. Imperium neoasyryjskie a Juda w polowie w. VIII, RTK 29 (1982) z. 1 , s. $29-44$.

146. Przymierze a przykazania noachickie (Rdz 9,1-17), ZN KUL 25 (1982) nr 1, s. 17-27.

\section{3}

147. Badania nad napomnieniami moralnymi św. Pawła w XX w. CT 53 (1983) fasc. 2, s. 47-64.

148. Koncepcja czlowieka w Starym Testamencie, w: MPWB t. 6, Lublin 1983, 13-23.

149. Wystąpienie Izajasza wobec Achaza, tamże, 111-128.

150. Eschatologia Księgi Izajasza, CT 53 (1983) fasc. 3, s. 25-36.

151. Usprawiedliwienie starotestamentalne a doskonałość ewangeliczna, w: Kultura życia wewnętrznego, Wrockaw 1983, 23-36.

152. Das Problem der Eschatologie im Buche Jesaja, CT 53 (1983) fasc. spec., s. $133-145$.

153. Die Erforschung der paulinischen Paränesen im XX. Jahrhundert, tamże, 177-194.

154. Dualizm w Piśmie św., art w: EK IV (1983). kol. 262-264. 280 .

155. Duch w Biblii i literaturze międzytestamentalnej, tamże, kol. 278-

156. Duch Boży, tamże, kol. 280-281.

157. Dusza ludzka III. A: Pismo św., tamże, kol. 381.

158. Dzień Jahwe, tamże, kol. 590-591.

159. El, tamże, kol. 872.

160. Elohim, tamże, kol. 900-901.

161. Eschatologia - ST, tamże, kol. 1107-1109.

162. Ewa, tamże, kol. 1368-1370.

\section{4}

163. Stary Testament o Bogu jedynym, transcendentnym i osobowym, w: W kręgu Dobrej Nowiny (red. J. Szlaga), Lublin 1984, 111-127. 
164. Druga pieśń o Słudze Jahwe (Iz 49,1-15), RTK 31 (1984) z. 1, s. $31-42$.

165. Maryja w Kanie Galilejskiej, w: U boku Syna (red. J. Szlaga), Lublin 1984, 85-94.

166. Od „zgromadzenia Jahwe” do Kościoła. Elementy eklezjalne w Starym Testamencie, w: Kościół w świetle Biblii (red. J. Szlaga), Lublin 1984, $9-20$.

\section{5}

167 Opowiadanie biblijne o potopie na tle historii początków, AK 95 (1985) 96-109.

168. Dary Ducha dla potomka Dawidowego oraz jego przyszle powszechne królestwo pokoju (Iz 11,1-10), w: MPFWB t. 6, Lublin 1985, 23-37

169. Groźby Tritoizajasza dla odstępców i obietnice dla gorliwych (Iz 65,1-25), RTK 32 (1985) z. 1, s. 33-46.

\section{6}

170. Książę pokoju (8,23b-9,6), RTK 33 (1986) z. 1, s. 23-35.

\section{7}

171. Społeczność Boża po powrocie z niewoli (Iz 56,1-12), RTK 34 (1987) z. 1, s. 5-22.

172. Co to jest eschatologia biblijna?, w: MPWB t. 8, Lublin 1987, 7-16.

173. Eschatologia w Iz 24-27, tamże, 41-50.

\section{8}

174. Potop biblijny, Lublin 1988 (wyd. 3, 1996), ss. 186 (Jak rozumieć Pismo św. 4).

175. Dawid a Saul na tle genezy monarchii izraelskiej, STV 26 (1988) nr 1 , s. $15-36$.

\section{9}

176. Rzeczy „dawne” i rzeczy „nowe” w wypowiedziach Deuteroizajasza, RTK 35 (1989) z. 1, s. 15-25.

177. Stary Testament $w$ świetle ostatnich badań krytycznych, RBL 42 (1989) 1-10.

178. Gehenna, art w: EK V, kol. 928.

179. Gilgamesz, tamże, kol. 1078-1079.

180. Głowa - ST, tamże, kol. 1139-1140.

181. Głód - ST, tamże, kol. 1146-1147.

182. Gnoza I. 1-4, kol. 1208-1210.

183. Góra - St, tamże, kol. 1368-1369.

\section{0}

184. Wstęp do Starego Testamentu (red. Stachowiak), Poznań 1990, ss. 496. (Wstęp do Pisma św. t. III).

185. Ogólna charakterystyka proroków, tamże, 237-270.

186. Prorocy więksi, tamże, 271-314.13

187. Księga Psalmów, tamże, 347-383. 
188. Założenia teologiczne jahwistycznego i kaplańskiego opisu potopu (Rdz 6,5-9,17), w: Studium Scripturae anima theologiae. Prace ofiarowane Ks. Prof. St. Grzybkowi (red. J. Chmiel, T. Matras), Kraków 1990, 291301.

\section{1}

189. Księga Izajasza. Thumaczenie, wstęp i komentarz, Lublin 1991, ss. 293, (Biblia Lubelska).

\section{2}

190. Akcenty ekologiczne w opisie potopu Rdz 6-9, RTK 38-39 (19911992) z. 1, s. 17-26.

\section{3}

191. Zbawcze działanie Boże a grzechy Izraela według Iz 59,1-21, w: Agnus et Sponsa. Prace ofiarowane o. Prof. A. Jankowskiemu OSB (red. T. Dąbek, T. Jelonek), Kraków 1993, 271-280.

192. Myśl religijna i teologiczna Księgi Izajasza, RT 40 (1993) z. 1, s. $21-41$.

193. Grzech - ST, art. w: EK VI (1983), kol. 265-267.

194. Grzech pierworodny I - ST, tamze, kol. 282.

195. Hebrajczycy, tamże, kol. 606-607.

\section{4}

196. Eschatologiczny los Jerozolimy i jej ludu. Refleksje biblijne nad Iz 66,6-25, LST 3 (1994) 239-246.

197. Problem prozelityzmu w judaizmie do I wieku po Chrystusie, RT 41 (1994) z. 1, s. 55-64.

\section{5}

198. Akcenty uniwersalistyczne w księgacb Jonasza i Rut, RT 42 (1995) z. 1 , s. $17-25$.

199. [Rec.] A. Świderkówna, Rozmowy o Biblii, ŁST 4 (1995) 245-246.

\section{6}

200. Geneza Księgi Izajasza 1-39, RT 43 (1996) z. 1, s. 43-53.

201. Księga Izajasza I (1-39). Wstęp - przekład z oryginału komentarz. Poznań 1996, ss. 500 (PSST IX, 1).

202. Księga Izajasza II-III (40-66). Wstęp - przekład z oryginału - komentarz - ekskursy. Poznań 1996, ss. 356.

203. Walka z kultem Baala w Starym Testamencie, w: Światła Prawdy Bożej. Ks. Prof. L. Stachowiakowi w 70. rocznicę urodzin (red. E. Szewc), Łódź 1996, s. 263-270.

\section{7}

204. Sprawiedliwość i doskonałość w Starym Testamencie, w: W posłudze Słowa Pańskiego. Księga pamiątkowa poświęcona Ks. Prof. J. Kudasiewiczowi z okazji 70-lecia urodzin (red. S. Bielecki i in.), Kielce 1997, 136-142. 
205. Księga Jeremiasza. Tłumaczenie, wstęp i komentarz. Lublin 1977 (Biblia Lubelska).

206. Isztar, art w: EK VII (1977)

207. Izajasz, tamże

208. Izajasza Księga, tamże

209. Izrael - ST, tamże

210. Jahwe, tamże

211. Jana Ewangelia, tamże

212. Jeremiasz, tamże

213. Jeremiasza Księga, tamże

214. Biblijna koncepcja etosu wyzwolenia spolecznego. w: Zycie społeczne w Biblii (red. A. Witaszek), Lublin 1997, 57-66.

\section{O. Franciszek Małaczyński OSB}

\section{Ś.P. O. ADRIEN NOCENT OSB $(1913-1996)$}

Dnia 9 grudnia 1996, w Opactwie św. Anzelma w Rzymie przeszedł do wieczności o. Adrien Nocent OSB, emerytowany profesor Akademii św. Anzelma, jeden $\mathrm{z}$ współzałożycieli Papieskiego Instytutu Liturgicznego i redaktor naczelny kwartalnika Ecclesia Orans. Miał 83 lata życia, 63 lata życia zakonnego i 58 lat kapłaństwa.

O. Nocent urodził się w Marcinelle w Belgii w roku 1913. Mając 19 lat wstapil do Opactwa benedyktyńskiego w Maredsous, gdzie otrzymał imię Adrian. Pierwsze śluby złożył 15 stycznia 1933 roku, 31 lipca 1938 roku został wyświęcony na kapłana. W czasie drugiej wojny światowej pełnił obowiązki kapelana wojskowego. Wolne chwile wykorzystywał na studium ojców Kościoła.

W czasie studiów teologicznych w Opactwie Mont-César w Louvain o. Nocent spotkał dwóch wybitnych autorów w dziedzinie liturgii: o. Bernarda Capelle i o. Bernarda Botte. Pod ich w pływem skoncentrował się na studiach liturgii. W roku 1952 zaczął wykładać w ośrodku "Lumen vitae” w Brukseli. W roku 1956, mając 43 lata, rozpoczął studia w Wyższym Instytucie Liturgicznym w Paryżu, równocześnie studiował w Ecole pratique des hautes études na Sorbonie. Obydwie uczelnie ukończył z dyplomami. W roku 1960 rozpoczął wykłady na Wydziale Teologicznym Papieskiej Akademii św. Anzelma w Rzymie. Razem z ojcami Salwatorem Marsili OSB i Cyprianem Vaggagini OSB zorganizowal Papieski Instytut Liturgiczny, 